\title{
A WATER RIGHTS TRADING APPROACH TO INCREASING INFLOWS TO THE ARAL SEA
}

\author{
M. Bekchanov ${ }^{1,3^{*}}$, C. Ringler ${ }^{2}$ and A. Bhaduri ${ }^{3}$ \\ ${ }^{1}$ International Water Management Institute (IWMI), 127 Sunil Mawatha, Pelawatta, \\ Battaramulla, Sri Lanka \\ ${ }^{2}$ International Food Policy Research Institute (IFPRI), Washington DC, USA \\ ${ }^{3}$ Center for Development Research (ZEF), GWSP, Walter-Flex Str 3, 53113 Bonn, \\ Germany
}

Corresponding author:

M. Bekchanov, International Water Management Institute (IWMI), 127 Sunil Mawatha, Pelawatta, Battaramulla, Sri Lanka.

E-mail: m.bekchanov@cgiar.org 


\begin{abstract}
Tremendous development of irrigation since the 1960s combined with unbalanced water resources management led to the destruction of the ecosystems in the delta zone and the gradual desiccation of the Aral Sea, once the fourth largest freshwater lake of the world. Command-and-control based water management in the Aral Sea Basin (ASB) inherited from Soviet times did not create any incentives for investing in improved irrigation infrastructure, adopt water-wise approaches, and thus maintain flows into the Aral Sea. This study examined the potential for market-based water allocation to increase inflows to the Aral Sea while maintaining stable agricultural incomes. We find that a water trading system can improve inflows to the Aral Sea but would require significant compensation for agricultural producers. Agricultural producers can use the compensation payments to cope with reduced water supply by improving irrigation and conveyance efficiencies and by developing alternative rural activities such as livestock grazing, agro-processing, and cultivation of low water consumptive crops. We also find that a water trading system would be more efficient if it includes both trade among irrigation sites and between sites and instream uses.
\end{abstract}

KEY WORDS: hydro-economic model; environmental flow; irrigation; water management institutions; Central Asia 
2 Land degradation has been commonly discussed as degradation of croplands due to soil 3 erosion, salinization and reduced water supply, and highlighted as a major problem

4 reducing soil fertility, decreasing agricultural outputs, and worsening environmental 5 conditions and rural livelihoods in many developing countries (Cerdà et al. 2009a, 2009b;

6 Zhao et al. 2013; Bizoza, 2014; Angassa, 2014). However, land degradation has a broader

7 meaning including also a degradation of wetlands, deforestation, overgrazing of meadows,

8 and desiccation of lakes and rivers. Decreasing ater availability due to inefficient use of

9 water for upstream irrigation and industrial purposes is a major reason for the degradation

10 of downstream ecosystems (e.g., desiccation of lakes, elimination of wetlands and

11 transformation of irrigated lands into fallow lands) (Falkenmark \& Rockström, 2004).

12 The enormous burden of upstream irrigation on downstream ecosystems and livelihoods is

13 nowhere more evident than in the Aral Sea Basin (ASB) of Central Asia (Micklin, 2007).

14 The Aral Sea case is often referred to as one of the worst manmade environmental disasters

15 of the 20th century (Micklin, 2007; Spoor \& Krutov, 2003). Diversion of river flows to

16 expand irrigation, particularly cotton production to achieve cotton self-sufficiency in the

17 Soviet Union, led to the drying of the lake and subsequently to the collapse of the local

18 economies in the surroundings of the lake (Micklin, 2010; Spoor \& Krutov, 2003). The

19 region which once held popular resorts and was a vibrant fish production center has now

20 turned into a desert-like area covered with a thick layer of salt and the Aral Sea is now

21 (ironically) called the Aral Desert (Aralkum; Breckle et al., 2012). Additional

22 consequences of the desiccation include dissemination of toxic salts blown from the dried

23 bed of the Sea, increasing soil salinization, degradation of irrigated lands, groundwater 
1 contamination, increasing seasonal temperature extremes, increasing air-borne diseases,

2 increasing unemployment and migration, and worsening living conditions (Micklin, 2007,

3 2010).

4 Given the increased understanding of the irreversible impacts of environmental disasters

5 and the large market and non-market values of ecosystem services, this study aims at

6 assessing the potential of market-based water allocation mechanisms to meet downstream

7 environmental needs in the Aral Sea by compensating agricultural water users for reduced

8 irrigation water use. Specifically, we compare the irrigation impacts and environmental

9 benefits of increasing environmental inflows into the Aral Sea, resulting water and land

10 use changes in irrigation sites, and necessary water rights transactions under two

11 experimental scenarios: with and without introducing water rights trading among the

12 irrigation water user sites. The compensation needs for reduced irrigation water for

13 agricultural producers and options for using these funds to increase water productivity are

14 analyzed as well.

15 Water rights trading among irrigation sites allows for additional gains from moving water

16 across irrigation sites due to the heterogeneity of irrigated crop production and the

17 possibility that more productive irrigation water users purchase the rights (Debaere et al.,

18 2014). Although administrative water management emphasizes the equity of water sharing

19 it has often led to water overuse and misallocation and poor quality of public agency

20 services (Dinar et al., 1997). Under water rights trading, the value of water is determined

21 through the trade relationships among the users (Rosegrant et al., 2000; Ringler et al.,

22 2004) and reflects not only delivery costs but also scarcity and opportunity costs of water

23 (Rogers et al., 2002) thus incentivizing water users not to waste water (Debaere et al., 
1 2014). Moreover, equity in water distribution can be addressed under water rights trading

2 through compensation to users with low water use efficiency who voluntarily transfer their

3 water use rights to more productive users (Dinar et al., 1997). Market-based approaches

4 for resource management can be of particular interest for transition economies, which often

5 have both the infrastructure and a need for such approaches but have as of yet little

6 experience in this area. To address this gap, this study provides an ex-ante analysis of

7 potential economic and environmental benefits from water rights trading in the ASB.

8 A river node based hydro-economic model was used to analyze the costs of compensating

9 irrigation water users for relinquishing parts of their water use rights to meet environmental

10 water needs of the Aral Sea. The model combines mass balances of river flow volumes

11 with statistically estimated irrigation water use and environmental flow benefit functions.

12 Environmental flow benefits considered are the sum of benefits from recreation, fishery,

13 navigation, wetlands and agro-ecosystem services (many other environmental benefits,

14 such as maintenance of stable groundwater levels, regulating microclimate, and cultural

15 values are not considered because of data limitations). Since irrigation accounts for more

16 than $90 \%$ of total water use and municipal and industrial sectors are prioritized over

17 irrigation in water allocation decisions in the ASB, changes in irrigation supplies are

18 basically the only source for increased flows into the Aral Sea. We therefore analyze water

19 use trade-offs between irrigation and instream flows at the basin level and do not consider

20 other water uses in this analysis. 


\section{MATERIALS AND METHODS}

2 River network scheme of the hydro-economic model

3 For analyzing the potential economic and environmental benefits of water rights trading

4 for the ASB compared to administrative water allocation, we developed a static hydro-

5 economic optimization model. To model river flow and off-takes along the river systems,

6 a river network scheme of the ASB was developed (Fig. 1).

7 Despite the introduction of management schemes based on basin boundaries in the ASB

8 administrative units (provinces) are still responsible for water offtake from the rivers and

9 internal distribution. Therefore, administrative provinces rather than hydrologic irrigation

10 units are considered as water user (irrigation) sites in the model. The river network scheme

11 of the model considers 12 water user sites and 19 river tributaries in the Syr Darya basin

12 and 14 water user sites and 13 river tributaries in the Amu Darya basin. These sites have

13 been clustered into separate water subcatchments (river nodes; Syr1 ...Syr4; Amu1 ...Amu5)

14 based on their closeness to one another.

\section{Model assumptions and equations}

16 Since water rights trading between different irrigation sites and environmental uses during

17 the growing season is the main focus of the study, reservoir operation, crop water use

18 scheduling, and monthly or weekly planning time steps were not considered in the model.

19 Furthermore, trading of water use rights is only allowed among irrigation sites within each

20 of the two river basin systems of the ASB since irrigation water users in the different rivers

21 are not connected to each other through a conveyance system. A basin management

22 organization (BMO) was assumed to coordinate and organize water rights trading through

23 buying and selling water use rights while taking into account the willingness of individual 
1 water users to pay for or purchase water rights given their demand function. The

2 International Fund for Saving the Aral Sea (IFAS) may represent the environmental agent

3 that raises the funds and compensates irrigators for relinquished water rights at less

4 productive production sites.

5 The set of variables, parameters and, equations of the model are presented in Tables S1 and

6 S2. The objective function of the model (Eq. 1) considers maximization of benefits from

7 irrigation and environmental water uses (Table S2). Irrigation benefits include agricultural

8 production benefits reduced by conveyance costs and are estimated regressing provincial

9 irrigation profits with total water withdrawals (Bekchanov, 2014) using a quadratic

10 function (Eq. 2). Quadratic irrigation water use functions are commonly used in the

11 literature (Zilberman et al., 1994; Ringler et al., 2006; Qureshi et al., 2007) and are also

12 recommendable here to capture the diminishing marginal returns of increased water use.

13 Environmental benefits are calculated as a linear function that depends on environmental

14 flows (Eq.3). The linear relationship between instream flows and benefits is estimated

15 based on observed water flows to the Aral Sea and benefits from wetlands, fisheries,

16 navigation, recreation, and reduced health and land degradation impacts of the desiccation

17 (see Bekchanov [2014] for more details).

18 The water balance equation at a river node has been modeled so that the sum of inflows

19 from upstream nodes, local supply sources, and return flow equals the sum of downstream

20 water releases and water offtakes for irrigation and industrial needs (Eq. 4). Total water

21 withdrawals at the province level depend on total irrigated area and the volume of water

22 use per hectare (Eq. 5). Total return flows are estimated as a fixed share of total withdrawals

23 (Eq. 6). 
1 Willingness to pay for water (Eq. 7) by irrigation sites is considered as a derivative from

2 irrigation benefit functions. Water use sites either buy or sell water use rights or do not

3 trade (Eq. 8). A market clearance relationship that requires equality of total water use rights

4 supply to the total demand of water use rights is included (Eq. 9). Moreover, water offtakes

5 to the irrigation sites are no higher than the sum of its water use rights and the additional

6 water bought if the user buys, or than the difference between water use rights and the

7 amount of water sold if the user sells (Eq. 10). To prevent economic losses from water

8 rights trading, total payments to buy water use rights are required to be no less than total

9 compensations for relinquished water use rights (Eq. 11).

\section{Scenarios}

11 The model was calibrated to the real conditions of land and water use and hydrologic flows

12 in 1999, a year with normal water supply. The year was chosen based on the average value

13 of the observed water supplies between 1980 and 2008. The initial water rights allocation

14 in the model is also based on water withdrawals by irrigation sites in 1999. For analyzing

15 the impact of water availability on water distribution among users, two alternative water

16 supply scenarios were assumed equivalent to $90 \%$ and $80 \%$ of the normal supply. The

17 lower water supply (80\%) was estimated based on an average of total observed water

18 supplies over the period between 1911 to 2008 (Dukhovny et al., 2008). Based on data

19 availability all economic costs and benefits were considered at price levels of 2006. Model

20 calibration and comparison of the baseline and optimized scenarios were discussed in

21 Bekchanov (2014) and Bekchanov et al. (2015) in detail.

22 Since the environmental benefits from inflows to the Aral Sea estimated from available

23 data at US\$0.004 per $\mathrm{m}^{3}$ were below those of the irrigation sector (optimal marginal 


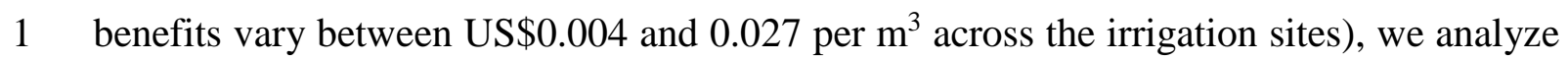

2 the impact of water rights trading for augmenting these flows by gradually increasing the

3 purchase of water use rights for this purpose. The gradual increase of water rights purchases

4 delivered to the Aral Sea and its delta (WBA) allows us to assess the accompanying

5 compensation requirements. Twenty-one cases of environmental flow acquisitions were

6 run varying from 0 to $20 \mathrm{~km}^{3}$. According to previous estimates, about $33-34 \mathrm{~km}^{3}$ of water

7 flow is required to maintain minimal environmental conditions in the Aral Sea and its delta

8 (Global Environmental Fund [GEF] 2002). Since the baseline scenario includes $13 \mathrm{~km}^{3}$ of

9 water flows to the Sea in an average hydrological year, to meet minimum flow

10 requirements would require an additional $20 \mathrm{~km}^{3}$ of water. Thus, increased purchases of

11 water rights from irrigation demand sites were considered for up to $20 \mathrm{~km}^{3}$.

12 To compare the economic and environmental benefits of market-based water allocation,

13 two experimental scenarios-with and without water rights trading among irrigation sites-

14 were run based on the model. For the latter case, the objective function and trading balance

15 restrictions were changed accordingly by setting water purchases by the irrigation sites

$16\left(W B_{d m}\right)$ equal to zero.

\section{Data sources}

18 Multiple sources of data were used to estimate the model parameters (for detailed

19 description of data and the parameters of irrigation and environmental benefit functions,

20 see Bekchanov, 2014, pp. 133-134 and pp. 216-221). Particularly, data on water supplies

21 in the source nodes (tributaries), land availability by irrigation sites, water withdrawals and

22 crop yields were obtained from SIC-ICWC (2011). Municipal and domestic water uses

23 were assumed as fixed amounts equal to $10 \%$ of total withdrawals (FAO 2012). Return 
1 flow rates across the irrigation sites were taken from EC-TACIS (1997) project reports.

2 Crop production costs, crop prices and revenues were estimated based on the reports of

3 local water management organizations and market surveys of regional research projects

4 (such as ZEF/UNESCO, 2001-2011 [http://www.zef.de/khorezm.0.html]; SIC-ICWC,

5 2008; Anderson \& Swinnen, 2008). Water delivery (conveyance) costs were obtained from

6 MAWR (2007). Approximate environmental benefits per unit of water inflow to the Aral

7 Sea were assessed based on previous studies summing up benefits of fishery, navigation,

8 wetlands, recreation, and reduced irrigation and health degradation impacts (INTAS, 2006;

9 for detailed assessment results, see Bekchanov, 2014).

\section{RESULTS}

12 Since in the short run, estimated marginal benefits of environmental flows were lower than

13 marginal irrigation water use benefits in this study, gradually increasing water use rights

14 for environmental needs would reduce total (sum of irrigation and environmental) benefits

15 (Fig. 2). When water use rights for environmental needs increase from 1 to $20 \mathrm{~km}^{3}$ in an

16 average water year, overall benefits decrease from US $\$ 1,901$ to US $\$ 1,608$ million (-15.4\%)

17 and from US $\$ 1,644$ to US $\$ 1,496$ million (-9\%) with and without considering water rights

18 trading among the irrigation sites, respectively. Likewise, under $80 \%$ of normal water

19 availability, overall benefits decline from US\$1,528 to US\$999 million (-34.6\%) and from

20 US $\$ 1,292$ to US\$972 million (-24.7\%) with and without considering water rights trading

21 among the irrigation sites respectively. While increased allocation of water rights for the

22 Aral Sea and its delta decrease total benefits, benefits remain larger, when water rights

23 trading among the irrigation sites is allowed, indicating significant gains from trading 
1 across irrigation sites. Allowing more productive producers to buy water use rights while

2 compensating for the reduced water uses of less productive producers provides higher

3 basinwide benefits than under the case without water rights trading among the irrigation

4 sites.

5

6 When water rights trading among the irrigation sites is allowed irrigation water users could

7 reduce total water use by $5 \mathrm{~km}^{3}$ and release it to the Aral Sea for US\$67.8 million in a

8 normal year (Fig. 3). The compensation cost of delivering $20 \mathrm{~km}^{3}$ of water into the Aral

9 Sea and its deltaic zones is estimated at US\$467 million. Compensation requirements of

10 providing additional environmental supplies increase with reduced water availability (river

11 runoff) since the value of water increases under water scarcity.

12 Increased environmental flow acquisitions would require a substantial reduction of

13 irrigation water withdrawals in many parts of the basin (Table I). When environmental flow

14 requirements of $20 \mathrm{~km}^{3}$ need to be satisfied and water rights trading is not allowed among

15 irrigation sites, the less productive upstream zones (Syr1 and Amu1) in both river basins

16 would reduce their water uses by $52 \%$ and $35 \%$, respectively. Even higher water use

17 reductions of $44 \%$ and $60 \%$ are required from the downstream irrigation subcatchments

18 (Syr4 and Amu5) that are located in arid zones and are characterized by high water losses.

19 In absolute terms, a larger volume of the environmental flows are acquired from the

20 irrigation catchments located in the Amu Darya Basin. For instance, downstream irrigation

21 sites of the Amu Darya Basin (Khorezm, Karakalpakstan, and Khorezm) are required to

22 relinquish a total of $6.4 \mathrm{~km}^{3}$ of their water use rights to meet environmental flow needs of

$2320 \mathrm{~km}^{2}$. Water use reductions are expected to occur through irrigated land use reductions

24 in the irrigation subcatchments of the midstream Amu Darya (Amu3), through per hectare 
1 water use reductions in the upstream and downstream reaches of the Syr Darya basin (Syr1

2 and Syr4), and through both irrigated area and per hectare water use reductions in the

3 upstream and downstream reaches of the Amu Darya basin (Amu1 and Amu5).

4 When water rights trading among irrigation sites is allowed some irrigation subcatchments

5 in the midstream reaches of the Amu and Syr Darya (Amu2, Syr2, Syr3) can increase their

6 water withdrawals and expand their irrigated lands (Table I). However, increasing

7 environmental flow acquisitions reduces irrigation water and land access to these irrigation

8 subcatchments.

9 As it is seen from the results, substantial irrigation water and land use reductions are

10 required to maintain minimum environmental flows to the Aral Sea. However, this is not

11 necessarily translated into abandonment of irrigated areas or substantial increases in

12 unemployment. Given the enormous water losses both in conveyance and during water

13 application because of very low distribution $(<60 \%)$ and irrigation efficiency $(<70 \%)$

14 (Bekchanov 2014) the potential of water use reductions is as high as 60-70\% in many

15 irrigation sites along the Amu and Syr Darya rivers if suitable technologies and

16 management practices are adopted.

\section{DISCUSSION}

19 Interpretation of model results for water and land use change to identify site-specific

20 options of reducing water demand

21 Based on the model results of water and land use changes (Table I), several options of

22 using compensation payments to improve water and land productivity and maintain rural

23 incomes can be recommended for each irrigation subcatchment considering their

24 geographic, physical and socio-economic characteristics (Table II). While interpretation of 
1 changes in total water and land uses is straightforward reduced water use per hectare

2 suggests multiple options such as improving irrigation and conveyance efficiencies,

3 replacing high water intensive crops (e.g., paddy rice) with less water intensive crops,

4 replacing irrigation with rainfed based crop production, and deficit irrigation. Increased

5 water use per hectare can be interpreted as implementation of double harvesting or

6 expansion of the production of high-value, high-water intensive crops.

7 Under increased environmental flow acquisitions when water rights trading among

8 irrigation sites is not allowed upstream irrigation sites (GBAO, Khatlon, RRT in the Amu

9 Darya Basin and Narin, Osh, Jalalabad in the Syr Darya Basin) can consider improving

10 irrigation efficiency (drip irrigation of fruits and vegetables), increasing rainfed areas while

11 reducing irrigated lands, developing the livestock sector, and replacing water intensive

12 crops, such as cotton, with low water consumptive ones, such as wheat and oats. In

13 midstream irrigation sites of the Amu Darya Basin (Lebap, Kashkadarya, Samarkand,

14 Navoi, Bukhara), improving irrigation efficiency (drip irrigation, laser guided land leveling

15 [Abdullaev et al., 2007], alternate dry furrows), reducing water intensive crop production,

16 such as replacing cotton with maize, and legumes, and other food crops, and implementing

17 deficit irrigation can help to improve water productivity. In the midstream irrigation sites

18 of the Syr Darya Basin (Tashkent, Syrdarya, Jizzakh, South Kazakhstan) improving

19 irrigation efficiency through laser guided land leveling and drip irrigation, and replacing

20 water intensive crops with low water consumptive ones would help reduce irrigation water

21 demand. In downstream regions (Khorezm, Karakalpakstan, Dashauz in the Amu Darya

22 basin and Kyzylorda in the Syr Darya Basin), in addition to reducing irrigated areas and

23 improving irrigation efficiency (laser guided land leveling) increasing conveyance 
1 efficiency through lining irrigation canals, developing the livestock sector (Bekchanov et

2 al., 2012), and replacing rice production with the production of less water consumptive

3 crops such as maize, sorghum, melons and gourds (Bobojonov et al., 2013) can play a great

4 role to reduce irrigation water demand. In highly saline marginalized lands in these

5 downstream irrigation sites cotton production could be entirely eliminated since it does not

6 cover the production costs and salt resistant trees that provide additional economic and soil

7 fertility improvement benefits such as Russian olive (Eleagnus angustifolia 1.) could be

8 grown (Djanibekov et al., 2012; Dubovyk et al., 2014). Similarly, growing licorice, whose

9 deep roots help flush away the salt in the soil, can help reclaim degraded lands and offers

10 farmers a profitable return for a relatively modest investment (Andrew Noble, personal

11 communication, April 15, 2015). Given the substantial post-harvest losses for fruits and

12 vegetables across growing sites in the ASB developing agro-processing industries,

13 especially in rural areas, can also boost incomes and improve water productivity across the

14 food supply chain (Bekchanov et al., 2014).

15 When water rights trading is allowed among irrigation sites while increasing environmental

16 flow acquisitions some more productive irrigation sites in the midstream reaches of both

17 river basins are recommended to expand irrigated areas and increase cropping intensity.

18 Expansion in Surkhandarya of the Amu Darya Basin could focus on double harvesting of

19 vegetables and expansion of citrus orchards given the longer period of warmer

20 temperatures in this region. In Tashkent, Syrdarya, and Jizzakh of the Syr Darya Basin,

21 considering the closeness of these regions to the major urban centers (Tashkent economic

22 zone), expansion of fruits, vegetables and other food crops, and development of 
1 greenhouses for extended, water-wise production could be considered to meet the demand

2 of close-by cities.

3 Uses of acquired environmental flows

4 As a result of relinquished irrigation water uses environmental flows in a normal year could

5 reach $33 \mathrm{~km}^{3}$ of water, which is still quite low compared to the annual Aral Sea inflows of

$650 \mathrm{~km}^{3}$ in the 1950s. However, this amount of water should be sufficient to reinstate some

7 of the ecosystem values and services in the Aral Sea and surrounding areas. Considering

8 the greater benefits from the wetland areas in the Aral Sea delta than the direct benefits of

9 shipping and fishery from the sea itself (Bekchanov 2014), environmental restoration

10 policies and projects should prioritize improving the environmental conditions in the

11 deltaic zone. Considering the limited availability of water resources, particularly in the

12 downstream reaches of the Amu Darya and Syr Darya Rivers, the possibilities of improving

13 water use efficiency and introducing effective institutions to enhance water availability in

14 the delta should be further investigated.

15 Newly launched campaigns of oil and gas drilling on the exposed areas of the Aral Sea bed

16 may reduce the political will to increase water inflow to the southern Aral Sea, thus

17 intentionally preventing restoration efforts of the sea (Micklin \& Aladin, 2008). However,

18 since the environmental resources benefit the entire society over generations, favoring

19 unilateral benefits from oil and gas mining should be reconsidered. Although

20 environmental benefit estimates provided in this study are quite low compared to irrigation

21 benefits and thus seem to justify the lack of governmental interest to increase flows into

22 the sea, these estimates addressed only a limited set of ecosystem services. Avoiding

23 underestimation of the environmental benefits in further research efforts by including the 
1 non-utilitarian values of environmental inflows, which can be much higher than the

2 utilitarian values (Freeman, 1993; Dziegielewska et al., 2009), may show an improved

3 balance of water for natural versus irrigation needs. Particularly, additional benefits from

4 increased environmental flow and reduced irrigation withdrawals for the local

5 microclimate, sustainable groundwater levels in the lower reaches, and reduced return

6 flows and river flow contamination should be taken into account in future studies in

7 addition to benefits from wetlands, fishery, navigation, recreation, and reduced health and

8 land degradation impacts of the desiccation.

9 Barriers for institutional change

10 Even though tradability of water rights among irrigation water users might provide higher

11 incomes than a system without tradable water use rights, as previously mentioned, setting

12 appropriate initial water use rights for each user, the rule of law, stakeholder participation,

13 and well developed irrigation infrastructure are prerequisites for the successful

14 performance of water rights trading (Debaere et al., 2014). Otherwise, additional gains

15 from water rights trading are not achievable or can prevent further market-based reforms

16 as has been seen in the case of Chile (Dellapena, 2005).

17 Within the last three decades, several initiatives have been launched to reduce the

18 ecological and economic problems in the ASB (Vinogradov \& Langford 2001; Weinthal,

19 2001). Particularly, the establishment of Basin Management Organizations (BVOs) in the

20 late 1980s, followed by the organization of the Interstate Committee for Water

21 Coordination (ICWC) in the early 1990s, and the adoption of several agreements on

22 improving livelihoods in the Circum-Aral Sea region since 1990 all fully or partially aimed

23 at preventing the ecological degradation in the ASB. Donors and international 
1 organizations such as the World Bank, USAID, GIZ and the International Fund for Saving

2 the Aral Sea (IFAS) with its multi-year basin management programs supported several

3 research projects and strongly influenced the introduction of Water User Associations

4 (WUAs) and water legislation improvements. Despite all these institutional changes and

5 organizational re-arrangements, the inherited administrative management system was

6 barely affected and no considerable improvement in water resources allocation has

7 occurred to date.

8 Increased understanding of the large potential benefits from incorporating economic and

9 market-based principles into water management and growing environmental consciousness

10 might nevertheless eventually lead to the implementation of water rights trading in the

11 basin. At present, basic steps towards market-based management in the water sector have

12 been realized in the ASB through introducing payments for water use by irrigating farmers

13 although the performance of these new institutional rules vary across the involved

14 countries. In Kazakhstan, where agricultural markets are more liberalized and farmers can

15 gain high incomes (Anderson \& Swinnen, 2010), paying for irrigation water is more

16 accepted than in other ASB countries where revenues of the majority of farmers hardly

17 cover their production costs. At the basin scale additional intergovernmental agreements

18 and the need for increased knowledge on river basin hydrology, resources, and production

19 levels may increase transaction costs of establishing market-based water allocation.

20 Previous estimates indicated that water rights trading cannot provide additional benefits in

21 the ASB when transaction costs exceed US $\$ 0.05$ per $^{3}$ (Bekchanov et al., 2015).

22 While compensation costs to irrigation farmers for reduced water consumption seems a

23 low-cost option compared to infrastructure development related options, such as inter- 
1 basin water transfers, raising funds for acquiring additional flows to the Aral Sea can be a

2 challenging task. Interested parties to improve the ecological and economic conditions in

3 the surroundings of the Aral Sea such as the riparian country governments, international

4 donors, private enterprises, and local communities are expected to contribute to raise the

5 funds for compensating for the irrigation water use reductions. The countries in the ASB

6 should closely collaborate and cooperate with each other to raise these funds and allocate

7 them to those irrigation sites who are reducing irrigation water use.

8 Regional cooperation which is essential for improved ecosystems, mutual benefits from

9 integrated energy and water use, and gains from trade are however not easily achievable

10 given the current unilateral development objectives of the Central Asian countries

11 (Djanibekov et al., 2015; O’Hara, 2000). Particularly, using reservoirs initially built in

12 Soviet times with the aim of improving downstream irrigation water supply to meet

13 upstream energy demand while neglecting the consequences on downstream reaches

14 (settlements, irrigated areas, and ecosystems) (Wegerich et al., 2007; Wegerich, 2008;

15 Dukhovny \& de Shutter, 2011) and following nationalistic policies of further irrigation

16 expansion by individual countries while ignoring the needs of other riparians (O'Hara,

17 2000) are just two examples that explain the reluctance or indifference of the riparian

18 countries to cooperate. Although there are inter-state agreements, laws, and institutions on

19 regional water allocation these laws are not adequately reflected in national legislations

20 and consequently inter-state water coordination organizations are not authorized to

21 exercise power to manage basin resources (O'Hara, 2000; Weinthal, 2001). The command-

22 and-control system inherited from the Soviet period does not create incentives for efficient

23 water use through optimal coordination of basin resources (Weinthal, 2001). Thus, 
1 introduction of tradable water use rights and generating benefits from basin-wide

2 coordination will take time in these transition countries and requires substantial pre-

3 reforms in institutions in contrast to the case of developed economies where market-based

4 management principles have been in practice for a long time. Increased awareness and

5 understanding of market-based management principles and environmental benefits,

6 empowering water stakeholders in water allocation processes, developing national water

7 management and development policies consistent with regional development goals and

8 boosting regional economic integration (Djanibekov et al., 2015) are pre-requisites for a

9 successful initiation of market-based water and environmental management policies in the 10 ASB.

\section{Model shortcomings}

12 Despite the provision of useful insights on water use trade-offs between irrigation and 13 instream flows to the Aral Sea, the model developed in this study is not free of 14 shortcomings. The model used here was developed to assess water use trade-offs between

15 agriculture and the environment at a macroeconomic scale and thus detailed accounts of 16 monthly water uses were not considered. However, additional insights on cropping patterns

17 and water uses over months can be further analyzed by developing an additional regional

18 agricultural production model. Inclusion of monthly flows and crop patterns in future

19 studies would allow more detailed analysis of crop pattern changes and seasonal water uses

20 as a response to increased re-allocation of water resources to Aral Sea flows. Consideration

21 of capital and labor inputs in addition to water in the crop production function can also

22 improve the results. 
1 Land use reductions, agricultural labor demand decrease, reduced food production, and

2 environmental changes are possible because of water use reductions in those sites that are

3 less productive and thus first sell water use rights to instream flows. However, since these

4 sites do receive compensation for their reduced benefits this income can be used to invest

5 in efficient irrigation technologies (Bekchanov et al., 2010) and agro-processing and

6 service industries that require less water (Bekchanov et al., 2014). Compensations can also

7 be used to purchase food from other, more productive irrigation sites through reliance of

8 the regions on each other's comparative advantages. Increased production in more

9 productive regions may increase labor demand in these provinces and can divert additional

10 labor from the regions where agricultural production decreases. However, the current

11 version of the model does not allow for an analysis of non-agricultural sector expansion,

12 inter-regional migration and commodity trade relationships which can be considered in

13 future studies with the availability of additional data.

14 The approximate environmental benefits in the model are based on a previous study

15 (INTAS 2006). However, this research project (INTAS 2006) seems to have determined

16 most ecosystem service benefits based on updating the results of surveys from the 1980s.

17 Therefore, more careful analysis of ecosystem service benefits in the ASB and delta zones

18 should be done by experts.

19 Despite its shortcomings, our model provides additional insights on the amount and

20 location of the required compensation payments for reduced irrigation water to improve

21 environmental flows into the Aral Sea and the potential of improved water allocation

22 efficiency through market-based water distribution. This study is also one of the first

23 studies to promote market-based management in transition economies where 
1 administrative management principles, which often result in inefficient resource allocation

2 and use, are dominant.

\section{CONCLUSIONS}

5 An improvement of the environmental system in the Aral Sea and surrounding areas can

6 likely be achieved by an additional average annual supply of $20 \mathrm{~km}^{3}$ of water to the Aral

7 Sea through compensating agricultural producers for voluntarily relinquishing irrigation

8 water rights. Compensation costs for additional environmental flows can be used by

9 farmers to cope with reduced irrigation water supply through improving water use

10 productivity and thus maintain stable incomes. Considering the local climate and

11 geographical conditions, farmers in different reaches of the rivers can choose those water

12 demand reduction measures that are most suitable to their local conditions. These include

13 improving irrigation and conveyance efficiencies, developing the agro-processing and

14 livestock sectors while reducing reliance on raw agricultural production, expanding rainfed

15 agriculture in feasible sites, introducing deficit irrigation, and replacing water intensive

16 crops, such as rice, with less water-consumptive crops (e.g., maize, gourds, legumes).

17 Although total irrigation and environmental benefits decrease with additional

18 environmental flow acquisitions since the estimated value of water for environmental needs

19 is lower than the value of irrigation water additional water acquisitions for environmental

20 needs can be more beneficial if additionally water rights trading among water user sites is

21 allowed. However, since market-based water management principles are quite new to both

22 water stakeholders (irrigation water users) and managers in water management

23 organizations these institutional, economic, and technical changes will take time to 
1 materialize. Increased research efforts involving water stakeholders and scientists from all

2 riparian countries, increasing environmental consciousness, and nourishing regional

3 cooperation and economic integration are also essential for the success of water and

4 environmental reforms in the ASB.

\section{ACKNOWLEDGEMENT}

7 The research is part of a $\mathrm{PhD}$ study conducted at the Center for Development Research

8 (ZEF) of Bonn University and was funded by the IPSWaT (International Postgraduate

9 Studies in Water Technologies) program of BMBF (German Ministry of Education and

10 Research). The authors are grateful to the CGIAR Research Program on Water, Land and

11 Ecosystems (WLE) for financial support during the process of writing the manuscript. The

12 authors are very grateful to Prof. Dr. Joachim von Braun (ZEF, Bonn University) and Dr.

13 Arnim Kuhn (ILR, Bonn University) for their review at the initial stages of preparing the

14 paper, and for two anonymous reviewers who provided very useful feedback.

15

16 Supporting Information

17 Table S1. Model parameters and variables

18 Table S2. Model equations 


\section{References}

Abdullaev I, Ul Hassan M, Jumaboev K. 2007. Water saving and economic impacts of land leveling: the case study of cotton production in Tajikistan. Irrigation and Drainage Systems 21(3-4): 251-263.

Anderson K, Swinnen J. 2008. Distortions to Agricultural Incentives in Europe's Transition Economies. World Bank: Washington, DC.

Angassa A. 2014. Effects of grazing intensity and bush encroachment on herbaceous species and rangeland condition in Southern Ethiopia. Land Degradation and Development 25: 438-451. doi: 10.1002/ldr.2160

Bekchanov M, Lamers JPA, Martius C. 2010. Pros and Cons of Adopting Water-Wise Approaches in the Lower Reaches of the Amu Darya: A Socio-Economic View. Water 2: 200-216. doi:10.3390/w2020200

Bekchanov M, Müller M, Lamers JPA. 2012. A Computable General Equilibrium Analysis of Agricultural Development Reforms: National and Regional Perspective. In Cotton, Water, Salts and Soums: Economic and Ecological Restructuring in Khorezm, Uzbekistan, Martius C, Rudenko I, Lamers JPA, Vlek PLG (eds). Springer: Dordrecht/Heidelberg/London/New York; 347-370.

Bekchanov M. 2014. Efficient water allocation and water conservation modeling in the Aral Sea Basin. PhD Thesis. Bonn University: Bonn. Available online at: http://hss.ulb.uni-bonn.de/2014/3609/3609.pdf.

Bekchanov M, Bhaduri A, Lenzen M, Lamers JPA. 2014. Integrating Input-Output Modeling with Multi-criteria Analysis to Assess Options for Sustainable Economic Transformation: The Case of Uzbekistan. In The Global Water System 
in the Anthropocene, Bhaduri A, Bogardi J, Leentvaar J, Marx S (eds). Springer: Dordecht/Heidelberg/London/New York; 229-245.

Bekchanov M, Bhaduri A, Ringler C. 2015. Potential gains from water rights trading in the Aral Sea Basin. Agricultural Water Management 152: 41-56.

Bobojonov I, Lamers JPA, Bekchanov M, Djanibekov N, Franz-Vasdeki J, Ruzimov J, Martius C. 2013. Options and constraints for crop diversification: a case study in sustainable agriculture in Uzbekistan. Journal of Agroecology and Sustainable Food Systems 37(7): 788-811. doi: 10.1080/21683565.2013.775539

Bizoza AR. 2014. Three-stage analysis of the adoption of soil and water conservation in the highlands of Rwanda. Land Degradation and Development 25: 360-372. doi: $10.1002 /$ ldr.2145

Breckle SW, Wucherer W, Dimeyeva LA, Oga NP (eds). 2012. Aralkum-a Man-Made Desert: Desiccated floor of the Aral Sea (Central Asia). Springer - Ecological Series, Vol. 218.

Cerdà A, Flanagan DC, le Bissonnais Y, Boardman J. 2009a. Soil Erosion and Agriculture. Soil and Tillage Research: 107-108. doi:10.1016/j.still.2009.10.006

Cerdà A, Giménez-Morera A, Bodí MB. 2009b. Soil and water losses from new citrus orchards growing on sloped soils in the western Mediterranean basin. Earth Surface Processes and Landforms 34: 1822-1830. doi:10.1002/esp.1889

Debaere P, Richter BD, Davis K., Duvall MS, Gephart JA, O'Bannon CE, Pelnik C, Powell EM, Smith TW. 2014. Water markets as a response to scarcity. Water Policy 16: 625-649. 
Dellapenna JW. 2005. Markets for water: time to put the myth to rest? Journal of Contemporary Water Research \& Education 131(1): 33-41.

Dinar A, Rosegrant MW, Meinzen-Dick R. 1997. Water allocation mechanisms (World Bank Policy Research Working Paper No. 1779). World Bank: Washington, DC. Djanibekov N, Valentinov V. 2015. Evolutionary governance, sustainability, and systems theory: The case of Central Asia. In Evolutionary Governance Theory: Theory and Applications, Beunen R, Van Assche K, Duineveld M (eds). Springer, Cham/Heidelberg/New York/Dordrecht/London; 119-134.

Djanibekov U, Khamzina A, Djanibekov N, Lamers JPA. 2012. How attractive are shortterm CDM forestations in arid regions? The case of irrigated croplands in Uzbekistan. Forest Policy and Economics 21: 108-117.

Dubovyk O, Menz G, Khamzina A, 2014 (in press). Land suitability assessment for afforestation with elaeagnus angustifolia $l$. in degraded agricultural areas of the lower Amudarya river basin. Land Degradation \& Development. doi: $10.1002 / 1 d r .2329$

Dukhovny VA, de Shutter JLG. 2011. Water in Central Asia: Past, Present, Future. Taylor and Francis: London.

Dukhovny VA, Sorokin AG, Stulina GV. 2008. Should we think about adaptation to climate change in Central Asia? SIC-ICWC: Tashkent. Available online at: www.cawater-info.net/library/eng/adaptation_climate_en.pdf (accessed on 20.07.2011) 
Dziegielewska D, Tietenberg T, Niggol SS. 2009. Total economic value. In Encyclopedia of Earth, Cleveland CJ (ed). Environmental Information Coalition, National Council for Science and the Environment: Washington, DC.

EC-TACIS. 1997. Formulation \& Analysis of Regional Strategies on Land and Water Resources: WARMAP Project Report. Tashkent: EC-TACIS.

Falkenmark M, Rockström J. 2004. Balancing water for humans and nature: The new approach in ecohydrology. Earthscan: London.

FAO. 2012. AQUASTAT (Online database). Available online at: http://www.fao.org/nr/water/aquastat/data/query/results.html (accessed on 20.11.2012)

Freeman M. 1993. The Measurement of Environmental and Resource Values: Theory and Methods. Resources for the Future: Washington, DC.

GEF (Global Environment Facility). 2002. Water and environmental management project: Subcomponent A1, Regional report No. 2. GEF Agency of the IFAS Aral Sea Basin Program: Tashkent (Uzbekistan).

INTAS. 2006. Final report: The rehabilitation of the ecosystem and bioproductivity of the Aral Sea under conditions of water scarcity. SIC-ICWC: Tashkent.

MAWR. 2007. Conveyance costs of delivering water to the irrigation sites in 2006 (Unpublished report). MAWR: Tashkent.

Micklin P. 2007. The Aral Sea Disaster. Annual Review of Earth Planetary Sciences 35: 47-72.

Micklin P, Aladin NV. 2008. Reclaiming the Aral Sea. Scientific American 298: 64-71. 
Micklin P. 2010. The past, present, and future Aral Sea. Lakes \& Reservoirs: Research \& Management 15(3): 193-213.

O’Hara S. 2000. Central Asia's water resources: contemporary and future manage-ment issues. Water Resources Development 16 (3): 423-441.

Qureshi ME, Connor J, Kirby M, Mainuddin M. 2007. Economic assessment of environmental flows in the Murray Basin. Australian Journal of Agricultural and Resource Economics 513: 283-303.

Ringler C, Huy NV, Msangi S. 2006. Water allocation policy modeling for the Dong Nai River Basin: an integrated perspective. Journal of American Water Resources Association 42: 1465-1482.

Ringler C, Von Braun J, Rosegrant MW. 2004. Water policy analysis for the Mekong River Basin. Water International 29(1): 30-42.

Rogers P, de Silva R, Bhatia R. 2002. Water is an economic good: how to use prices to promote equity, efficiency, and sustainability. Water policy 4(1): 1-17. doi:10.1016/S1366-70117(02)00004-1

Rosegrant MW, Ringler C, McKinney DC, Cai X, Keller A, Donoso G. 2000. Integrated economic-hydrologic water modeling at the basin scale: the Maipo river basin. Agricultural Economics 24(1): 33-46.

SIC-ICWC. 2008. Data on crop production costs and benefits collected from different SIC-ICWC reports (Unpublished).

SIC-ICWC. 2011. CAREWIB (Central Asian Regional Water Information Base). Available online at: www.cawater-info.net (Accessed on 27.01.2012) 
Spoor M, Krutov A. 2003. The 'power of water' in a divided Central Asia. Perspectives on Global Development and Technology 2(3-4): 593-614.

Vinogradov S, Langford VPE. 2001. Managing transboundary water resources in the Aral Sea basin: In search of a solution. International Journal of Global Environmental Issues 1: 345-362.

Wegerich K, Olsson O, Froebrich J. 2007. Reliving the past in a changed environment: hydropower ambitions, opportunities and constraints in Tajikistan. Energy Policy 35 (7): 3815-3825.

Wegerich K. 2008. Hydro-hegemony in the Amu Darya Basin. Water Policy 10 (5): 7188.

Weinthal E. 2001. Sins of Omission: Constructing Negotiating Sets in the Aral Sea Basin. Journal of Environment \& Development 10(1): 50-79.

Zhao G, Mu X, Wen Z, Wang F, Gao P. 2013. Soil erosion, conservation, and Ecoenvironment changes in the Loess Plateau of China. Land Degradation \& Development 24: 499- 510. 2013. doi:10.1002/ldr.2246

Zilberman D, Macdougall N, Shah F. 1994. Changes in water allocation mechanisms for Californian agriculture. Contemporary Economic Policy 12(1): 122-133. 


\section{Tables}

Table I. Water withdrawals, water rights sold or bought by irrigation sites, and changes in irrigated area under increasing water acquisitions for the Aral Sea with and without water rights trading among irrigation sites

\begin{tabular}{|c|c|c|c|c|c|c|c|c|c|c|c|c|c|c|c|c|}
\hline \multirow{3}{*}{$\begin{array}{l}\text { A group of } \\
\text { irrigation sites }\end{array}$} & \multicolumn{5}{|c|}{ Water withdrawals } & \multicolumn{5}{|c|}{$\begin{array}{l}\text { Water rights sold }(-) \text { or bought }(+)\left(\mathrm{km}^{3}\right) \text { by } \\
\text { irrigation sites }\end{array}$} & \multicolumn{5}{|c|}{ Irrigated land use } & \multirow{3}{*}{$\begin{array}{l}\text { Options fo } \\
\text { reducing } \\
\text { water } \\
\text { demand** }\end{array}$} \\
\hline & \multirow{2}{*}{$\begin{array}{l}\text { Base } \\
\left(\mathrm{km}^{3}\right)\end{array}$} & \multicolumn{4}{|c|}{ Change (\%) } & \multirow{2}{*}{$\begin{array}{l}\text { Base } \\
\left(\mathrm{km}^{3}\right)\end{array}$} & \multicolumn{4}{|c|}{ Scenarios* } & \multirow{2}{*}{$\begin{array}{l}\text { Base } \\
\text { (mln } \\
\text { ha) }\end{array}$} & \multicolumn{4}{|c|}{ Change (\%) } & \\
\hline & & Sc5 & Sc10 & Sc15 & Sc20 & & Sc5 & Sc10 & Sc15 & Sc20 & & Sc5 & Sc10 & Sc15 & Sc20 & \\
\hline \multicolumn{17}{|c|}{ Without water rights trading among irrigation sites } \\
\hline Amu1 & 5.6 & -31 & -41 & -50 & -52 & -0.6 & -2.3 & -2.8 & -3.4 & -3.5 & 444 & -6 & -12 & -12 & -12 & $\mathrm{w} \downarrow \mathrm{L} \downarrow$ \\
\hline Amu2 & 3.1 & 0 & 0 & 0 & 0 & 0.0 & 0.0 & 0.0 & 0.0 & -0.0 & 344 & 0 & 0 & 0 & 0 & 0 \\
\hline Amu3 & 7.6 & 2 & -16 & -18 & -19 & -0.1 & 0.0 & -1.4 & -1.5 & -1.6 & 721 & 0 & -17 & -17 & -17 & $\mathrm{~L} \downarrow$ \\
\hline Amu 4 & 13.8 & -6 & -9 & -13 & -15 & 0.0 & -0.9 & -1.2 & -1.7 & -2.1 & 1922 & 0 & 0 & 0 & 0 & $\mathrm{w} \downarrow$ \\
\hline Amu5 & 14.6 & -2 & -11 & -20 & -44 & 0.0 & -0.3 & -1.5 & -2.9 & -6.4 & 905 & 0 & -5 & -5 & -21 & $\mathrm{wL} \downarrow$ \\
\hline Syr1 & 1.5 & 4 & -26 & -32 & -35 & -1.2 & -1.2 & -1.6 & -1.7 & -1.8 & 182 & 31 & 0 & 0 & 0 & $\mathrm{w} \downarrow$ \\
\hline Syr2 & 9.9 & 0 & -1 & -9 & -14 & -0.1 & -0.1 & -0.1 & -0.9 & -1.4 & 1078 & 0 & 0 & -4 & -4 & $\mathrm{wL} \downarrow$ \\
\hline Syr3 & 9.1 & 0 & -7 & -12 & -12 & -0.3 & -0.3 & -0.9 & -1.4 & -1.4 & 1418 & 0 & 0 & 0 & 0 & $\mathrm{w} \downarrow$ \\
\hline Syr4 & 3.1 & 0 & -13 & -45 & -60 & 0.0 & 0.0 & -0.4 & -1.4 & -1.9 & 131 & 0 & 0 & 0 & 0 & $\mathrm{w} \downarrow$ \\
\hline \multicolumn{17}{|c|}{ With water rights trading among irrigation sites } \\
\hline Amu1 & 5.6 & -52 & -52 & -53 & -54 & -0.6 & -3.5 & -3.5 & -3.5 & -3.6 & 444 & -12 & -12 & -12 & -12 & $\mathrm{w} \downarrow \mathrm{L} \downarrow$ \\
\hline Amu2 & 3.1 & 31 & 30 & 26 & 22 & 0.0 & 1.0 & 0.9 & 0.8 & 0.7 & 344 & 18 & 18 & 18 & 18 & $\mathrm{w} \uparrow \mathrm{L} \uparrow$ \\
\hline Amu3 & 7.6 & -8 & -9 & -13 & -22 & -0.1 & -0.7 & -0.9 & -1.2 & -1.8 & 721 & -9 & -9 & -9 & -13 & $\mathrm{w} \downarrow \mathrm{L} \downarrow$ \\
\hline Amu4 & 13.8 & 4 & -1 & -15 & -30 & 0.0 & 0.5 & -0.2 & -2.0 & -4.1 & 1922 & 1 & 1 & 1 & 1 & $\mathrm{w} \downarrow$ \\
\hline Amu5 & 14.6 & -16 & -44 & -61 & -70 & 0.0 & -2.3 & -6.4 & -8.9 & -10.3 & 905 & 1 & -21 & -21 & -21 & $\mathrm{w} \downarrow \mathrm{L} \downarrow$ \\
\hline Syr1 & 1.5 & -43 & -43 & -43 & -43 & -1.2 & -1.9 & -1.9 & -1.9 & -1.9 & 182 & 0 & 0 & 0 & 0 & $\mathrm{w} \downarrow$ \\
\hline Syr2 & 9.9 & 13 & 13 & 12 & 8 & -0.1 & 1.3 & 1.3 & 1.2 & 0.7 & 1078 & 13 & 13 & 13 & 13 & $\mathrm{~L} \uparrow$ \\
\hline Syr3 & 9.1 & 31 & 31 & 30 & 26 & -0.3 & 2.5 & 2.5 & 2.5 & 2.1 & 1418 & 11 & 11 & 11 & 11 & $\mathrm{w} \uparrow \mathrm{L} \uparrow$ \\
\hline Syr4 & 3.1 & -60 & -60 & -60 & -60 & 0.0 & -1.9 & -1.9 & -1.9 & -1.9 & 131 & 0 & 0 & 0 & 0 & $\mathrm{w} \downarrow$ \\
\hline
\end{tabular}

Notes: $*$ Sc5, Sc10, Sc15, Sc20 are scenarios for water acquisitions for the Aral Sea of to 5, 10, 15, and $20 \mathrm{~km}^{3}$, respectively.

$* * 0$-no change, $\mathrm{w} \downarrow$-per hectare water use reduction if total water use decreased but total land use did not change; $\mathrm{L} \downarrow$ - land use reduction if total land and water use decreased at similar rates; $\mathrm{w} \downarrow \mathrm{L} \downarrow-$ both per hectare water use and total land use reduction if total water use reduction rates are higher than total land use reduction rates; $\mathrm{L} \uparrow$ - land use increase if total land and water use increased at similar rates; w $\uparrow \uparrow \uparrow$ - both per hectare water use and total land use increase if total water use increase rates are higher than total land use increase rates. 
Table II. Improved water management strategies for irrigation sites with and without water use rights trading when environmental flow acquisitions are increased

\begin{tabular}{|c|c|c|c|c|c|c|c|c|}
\hline \multirow[b]{2}{*}{$\begin{array}{l}\text { A group } \\
\text { of } \\
\text { irrigation } \\
\text { sites } \\
\end{array}$} & \multicolumn{6}{|c|}{ Water use reduction options } & \multicolumn{2}{|c|}{$\begin{array}{l}\text { Increased irrigation water } \\
\text { withdrawals }\end{array}$} \\
\hline & $\begin{array}{l}\text { Improving } \\
\text { irrigation } \\
\text { efficiency } \\
\end{array}$ & $\begin{array}{l}\text { Improving } \\
\text { conveyance } \\
\text { efficiency }\end{array}$ & $\begin{array}{l}\text { Replacing high } \\
\text { water intensive } \\
\text { crops (e.g., } \\
\text { paddy rice) } \\
\text { with less water } \\
\text { intensive crops }\end{array}$ & $\begin{array}{l}\text { Increasing } \\
\text { rainfed } \\
\text { areas } \\
\end{array}$ & $\begin{array}{l}\text { Deficit } \\
\text { irrigation }\end{array}$ & $\begin{array}{l}\text { Reducing } \\
\text { irrigated } \\
\text { areas } \\
\end{array}$ & $\begin{array}{l}\text { Irrigated } \\
\text { area } \\
\text { expansion } \\
\end{array}$ & $\begin{array}{l}\text { Extending high water } \\
\text { intensive crops with } \\
\text { high profitability } \\
\text { (vegetables, fruits, } \\
\text { double harvesting in } \\
\text { urban area peripheries) }\end{array}$ \\
\hline \multicolumn{9}{|c|}{ Without water rights trading among irrigation sites } \\
\hline Amu1 & + & & + & + & & + & & \\
\hline \multicolumn{9}{|l|}{ Amu2 } \\
\hline Amu3 & & & & & & + & & \\
\hline Amu4 & + & & + & & + & & & \\
\hline Amu5 & + & + & + & & + & + & & \\
\hline Syr1 & + & & + & + & + & & & \\
\hline Syr2 & + & & + & & + & & & \\
\hline Syr3 & + & & + & & & & & \\
\hline Syr4 & + & + & + & & & & & \\
\hline \multicolumn{9}{|c|}{ With water rights trading among irrigation sites } \\
\hline Amu1 & + & & + & + & & + & & \\
\hline Amu2 & & & & & & & + & + \\
\hline Amu3 & + & + & & & + & + & & \\
\hline Amu4 & + & & + & & + & & & \\
\hline Amu5 & + & + & + & & + & + & & \\
\hline Syr1 & + & & + & + & + & & & \\
\hline Syr2 & & & & & & & + & \\
\hline Syr3 & & & & & & & + & + \\
\hline Syr4 & + & + & + & & & & & \\
\hline
\end{tabular}

